\title{
Immunological Heterogeneity of Pili of Neisseria gonorrhoeae
}

\author{
By P. NOVOTNY AND W. H. TURNER \\ Department of Bacteriology, Wellcome Research Laboratories, \\ Beckenham BR3 3BS, Kent
}

(Received I3 November 1974; revised 24 January 1975)

\section{SUMMARY}

Sera of rabbits immunized with pili or formalized cultures of Neisseria gonorrhoeae contained pili antibodies. The reaction between pili and specific gamma globulin was followed by direct visual observation with an electron microscope. Using pili from 3I strains and antisera against three strains, only a few crossreactions between pili were observed. From this it is concluded that gonococcal pili are antigenically heterogeneous. However, serum raised with a $T_{3}$ culture (with no detectable pili) contained antibodies against pili of the homologous T2 strain. It is proposed that the pilus antigen may exist in a form different from the typical pilus in gonococci.

\section{INTRODUCTION}

Since gonococcal pili have been detected only in cultures of the virulent $\mathrm{T} I$ and $\mathrm{T} 2$ colonial forms and not in $T_{3}$ and $T_{4}$ cultures (using the classification of Kellogg et al. 1963), it has been suggested that there may be a relationship between pili and virulence (Jephcott, Reyn \& Birch-Andersen, 197I) and that the pili are 'the first component or type of attachment' of gonococci to amnion cells (Swanson, 1973). For this reason, interest has centred on the role of pili in the pathogenicity of gonococci.

It has been assumed from an indirect test that gonococcal pili are immunologically homogeneous (Buchanan et al. 1973). Since we were unable to prepare pure pili without contamination with free endotoxin in our laboratory, we decided to use immune electron microscopy (Almeida \& Waterson, 1969) for the immunological study of pili. This technique has been used for the study of pili by Lawn \& Meynell (1970); as it is based on direct visual evidence of the reaction between immune globulin and a particulate antigen, it is not necessary to use pure antigens and monospecific sera (Turner \& Novotny, 1974).

\section{METHODS}

Organisms. Freshly isolated strains of Neisseria gonorrhoeae were mainly used. The majority of these, the stg strains, were from pus obtained for us by Dr D. Wright, which had been isolated from males in a VD clinic at St Giles' Hospital, London, S.E.5; two strains, PatI and CN6826, were from pus obtained for us by Dr C. S. Ratnatunga, The Prince of Wales' General Hospital, London, N.15; one strain, C206, was from this laboratory; strain 9 was obtained by Dr D.S. Kellogg, General Disease Research Laboratory, National Communicable Disease Centre, Atlanta, Georgia, U.S.A., and strain 2868 by Dr T. M. Buchanan, The Rockefeller University, New York, U.S.A.

Preparation of antigen. Cultures were grown either on GC agar (Difco) plates with supplements (Kellogg et al. 1963) or in liquid GC medium (Difco Manual, I97I ; formula with agar 
omitted) in a fermenter (Novotny, Short \& Walker, 1975). After 4 to 5 doublings of the bacterial mass the cultures were spun down and the sediments layered on a 5 to $40 \%(\mathrm{w} / \mathrm{v})$ sucrose linear gradient in $\mathrm{I} \mathrm{M}-\mathrm{NaCl}$ and centrifuged for $30 \mathrm{~min}$ at $400 \mathrm{~g}$. The top layer containing mainly pili was collected, washed twice by centrifugation at $10000 \mathrm{~g}$ for $20 \mathrm{~min}$ and used for the test. For cross-reaction determinations, overnight cultures on GC plates were either used for the preparation of pili by sucrose gradient, or the cells were resuspended in distilled water and used directly as antigen. In each case the density of pili was checked in the electron microscope before the test.

Preparation of antisera. Sera were prepared by immunizing rabbits with either pili preparations from sucrose gradients or with formalized $(\mathrm{I} \%, \mathrm{v} / \mathrm{v})$ whole cell suspensions containing approximately $10^{10}$ cells $/ \mathrm{ml}$. Strains stG4, stG38 and Pat I were used. With all three strains the cultures consisted predominantly of T2 colonial forms. One rabbit was also immunized with a non-piliated $\mathrm{T}_{3}$ culture suspension derived from strain Pat $\mathrm{I}$. Basic immunization consisted of two intramuscular doses $(2 \mathrm{ml})$ of antigen suspension in incomplete Freund adjuvant given two weeks apart. Three weeks after the second injection, antigen precipitated with alum was injected intravenously in six bi-weekly doses starting at $0.05 \mathrm{ml}$ and inceasing to $0.4 \mathrm{ml}$. Seven to ten days after the last injection the rabbits were bled. Before use the sera were heated for $30 \mathrm{~min}$ at $56^{\circ} \mathrm{C}$.

The test. A suspension ( $0.1 \mathrm{ml})$ of either concentrated pili or whole bacterial cultures from solid or liquid media, containing approximately $10^{9} \mathrm{pili} / \mathrm{ml}$, was mixed with equal volumes

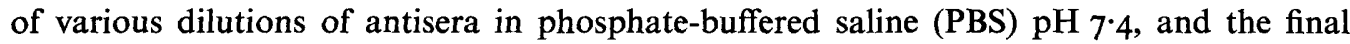
volume adjusted to 0.5 to $\mathrm{I} \cdot 0 \mathrm{ml}$ with PBS. After overnight incubation at $4{ }^{\circ} \mathrm{C}$ the mixtures were centrifuged at $12000 \mathrm{~g}$ for $20 \mathrm{~min}$, the sediments washed with PBS and, after recentrifugation, the supernatants carefully and completely withdrawn. Each pellet was resuspended in a few drops of distilled water, mixed immediately with an equal volume of $3 \%(\mathrm{w} / \mathrm{v})$ sodium phosphotungstate $\mathrm{pH} 7 \cdot 6$, and transferred to carboned Formvar-coated grids (400 mesh). After drying, the specimens were observed in a Philips EM300 electron microscope at $80 \mathrm{kV}$ using a magnification on the main screen of 48400 . All specimens were negatively stained with sodium phosphotungstate.

\section{RESULTS}

The pili preparations tested were contaminated to a greater or lesser extent with free endotoxin blebs of different shapes and sizes. When whole cultures were used, the cells or their fragments did not interfere with the reaction. The pili present in specimens were either dispersed as individual pili or appeared as bundles or aggregates packed closely together. When the preparations were treated with a negative serum no changes were seen on either of the structures (Fig. I). However, in reactions with homologous antiserum at low final dilutions ( $\mathrm{I} / 5$ to $\mathrm{I} / \mathrm{IO}$ ), pili were completely coated with aggregates of antibodies (Fig. 6). To see the individual antibody molecules it was necessary to dilute the antiserum to $\mathrm{I} / 50$ or more (Fig. 5). The highest final dilution of hyper-immune antisera at which it was possible to see the antibodies on the screen was $\mathrm{I} / 400$. Rabbit sera obtained after injecting two doses of antigen in adjuvant were usually without, or almost without, antibodies reacting with pili and unsuitable for immune electron microscopy. When the pili were separated from one another, reaction with antiserum brought about agglutination of the pili. When bundles of agglutinated pili resulted in this way, the individual pili were separated from one another by reacting antibodies (Fig. 6). These were easily distinguished from the bundles of pili which were present before the antiserum was added, since in this case the pili were closely packed together (Fig. 2). 

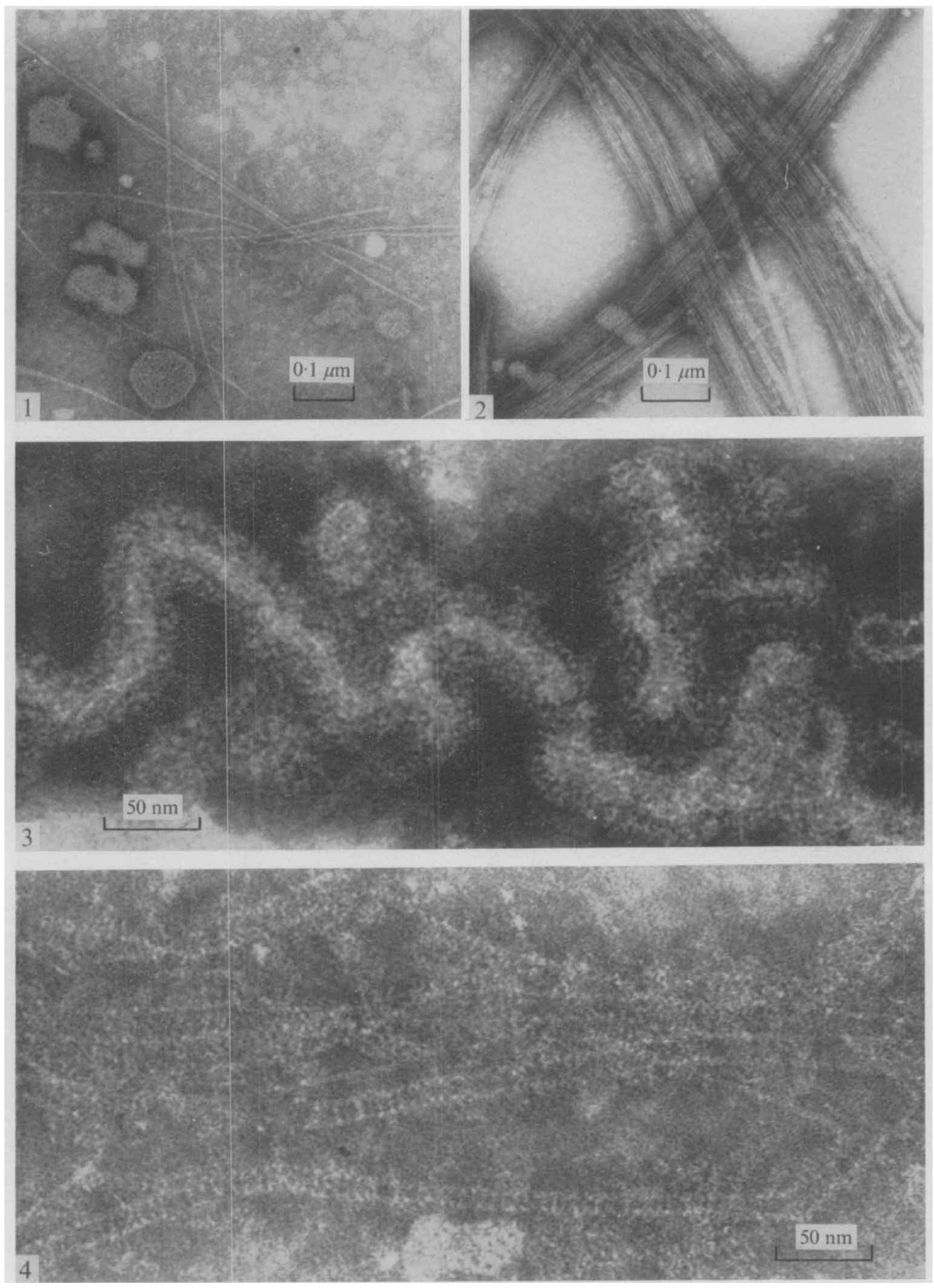

Fig. I. Particulate entities in cultures of $N$. gonorrhoeae: pili and bizarre forms of free endotoxin blebs after reaction with a negative control serum (strain C206).

Fig. 2. Strain stg38 pili. Bundles of pili appearing in some cultures are closely packed together. These bundles differ in appearance from pili agglutinated by antibodies (compare with Fig. 6).

Fig. 3. Bizarre, free endotoxin bleb, heavily coated with antibodies. Specimen of strain PatI reacting with homologous antiserum in a final dilution of $\mathbf{I} / \mathbf{I} 0$.

Fig. 4. Strain stg28 pili reacting with strain stg4 antiserum in a final dilution of $\mathrm{I} / \mathrm{IO}$. Antibodies forming a 'ladder' between pairs of pili. The distance between pili is 10.0 to $13.0 \mathrm{~nm}$ and the distance between antibodies is approximately $6.0 \mathrm{~nm}$. 



Fig. 5. Reaction of strain PatI pili with homologous antiserum. In a final dilution of $1 / 50$ in the reaction mixture individual molecules of antibodies are visible. Note the free endotoxin bleb with apparent fine surface structure and only 2 to 3 combining antibodies.

Fig. 6. In the cross-reaction here (strain stG4 pili with strain stG38 antiserum) the pilus with a knob on one end seems to be completely unlabelled with antibodies, in contrast to the agglutinated and heavily labelled bundle of pili. 
Table I. Direct immune reaction of Neisseria gonorrhoeae sera with pili of different strains

\begin{tabular}{|c|c|c|c|c|}
\hline \multirow[b]{2}{*}{ Pili of strain } & \multicolumn{3}{|c|}{ Antisera } & \multirow{2}{*}{$\begin{array}{l}\text { Provisonal } \\
\text { scheme of } \\
\text { pili antigen }\end{array}$} \\
\hline & Pat I & stG4 & stG3 8 & \\
\hline pat I & $\oplus$ & + & - & $A(b)^{*}$ \\
\hline stG4 & - & $\oplus$ & + & BCe \\
\hline stg38 & - & + & $\oplus$ & $\mathrm{Cd}$ \\
\hline StG2 & - & - & + & d \\
\hline StGI 8 & - & + & + & $\mathrm{de}$ \\
\hline StG25 & - & + & - & e \\
\hline stG26 & - & + & - & e \\
\hline stg28 & - & + & - & e \\
\hline $\begin{array}{l}\text { stG } 6,7,8,9,10, \text { I I, I 2, } \\
\text { I } 3,15,17,19,20,21 \text {, } \\
22,27,29,30,31,32\end{array}$ & - & - & - & \\
\hline & - & - & - & \\
\hline
\end{tabular}

$\oplus$, Positive homologous reaction; + , positive heterologous reaction; - , negative reaction at final serum dilution of $1 / 5$.

* Serum against stG4 reacted with PatI pili but not vice versa.

To determine the cross-reactivity of pili of different strains, the final dilution of sera normally used in the mixture was $\mathrm{I} / 5$ to I/IO. Serum against strain Pat I (T2 cells) reacted with homologous pili only. Serum against non-piliated $T_{3}$ cells of the same strain contained antibodies against homologous $\mathrm{T} 2$ pili which were visible at a final dilution of $\mathrm{r} / 50$. Serum against StG4 strain (T2 cells) was the most polyvalent serum obtained. It reacted with strain Pat I pili (although anti-Pat I serum did not react with StG4 pili) as well as with five other strains. The serum raised against T2 cells of stg38 strain gave fewer cross-reactions. However, $70 \%$ of the strains tested (22 out of 31 ) did not react with any of the sera available, which suggests that the pili of $N$. gonorrhoeae are serologically heterogeneous (Table $\mathrm{I}$ ).

During the course of these investigations it was found that pili produced by the same strain are not always serologically homogeneous since some of the pili failed to react with homologous antibody. The same phenomenon was found more often in heterologous reactions. In Fig. 6 it can be seen that the non-reacting pilus has a knob on one end; this type of pilus (pili $c$ according to Novotny et al. 1975) is morphologically similar to sex pili in Escherichia coli (Lawn \& Meynell, 1970). Occasionally it was possible to see that the antibodies between two adjacent pili were attached in a regular ladder-like pattern (Fig. 4). This was observed in homologous reactions with diluted sera (strains PatI and StG4) as well as in heterologous reactions (strains StG25, StG26 and StG28).

The reaction between free endotoxin blebs and antibodies was heterogeneous. Usually endotoxin blebs on which the fine structure was visible did not react or did so very sparsely (Fig. 5), while blebs with no visible structure reacted heavily (Fig. 3). Several cross-reactions were observed although these did not correlate with the cross-reactions of pili.

\section{DISCUSSION}

From this study it is evident that the gonococcal pili are antigenically heterogeneous, since few serological cross-reactions occurred between pili of different strains. In several cases the titre of antibodies to heterologous pili appeared to be lower than the titre against the homologous strain, which suggests that even when the pili cross-reacted they were not necessarily serologically identical. The ladder-like pattern formed by antibodies between two 
adjacent pili indicates that the antigenic loci reacting with the antibodies appeared in these cases to be regularly distributed along the length of the pilus at a distance of about $6.0 \mathrm{~nm}$, suggesting that the pilus is composed of regularly repeating segments. The scheme in Table I summarizes the results so far obtained; the cross-reactivities are expressed by letters.

The reactivity of sera obtained by hyper-immunization with non-piliated $\mathrm{T}_{3}$ cells (which had been passaged more than 50 times during which there was no reversion to T2 colonies) suggests that the pilus antigen was contained in the $T_{3}$ cells. This result is in keeping with the proposal of Novotny et al. (1975) that the most common pili in gonococci (pili $a$ ) are actually a component of cell walls which under certain conditions give rise to structures which have the appearance of pili in $T_{1}$ and $T_{2}$ cells.

The fact that free endotoxin blebs on which the fine structure was visible reacted with antibodies only weakly if at all, whereas blebs with no visible surface structure reacted readily and showed several cross-reactions between strains, tends to support the assumption that the most superficial cell wall L-layer which gives rise to free endotoxin is actually coated with a fine structure which can be removed (Novotny et al. 1975).

In the serologial test introduced by Buchanan et al. (I973), in which purified pili of strain 2868 were used as antigen, relatively high reactivity with sera from different patients was obtained. This seems not to be in accordance with our direct observations of the reaction between specific immune $\gamma$-globulin and the pili of gonococci isolated from patients in a relatively small regional VD clinic. Pili of strain 2868 did not react with any of our sera. This discrepancy deserves further elucidation. However, it would be interesting to know whether the serological heterogeneity of gonococcal pili can be used in epidemiological studies and whether the cross-protection in the guinea-pig model (Arko, 1972) is paralleled by the crossreactivity of pili. These questions are being studied.

We are grateful to Dr June Almeida, Department of Virology, Wellcome Research Laboratories, Beckenham, for the introduction to the technique of immune electron microscopy and helpful criticism, to Dr C. S. Ratnatunga and Dr D. Wright for help in obtaining pus from gonorrhoic males, and to Dr D. S. Kellogg and Dr T. M. Buchanan for providing strains. We thank Mr J. A. L. Short, Miss Christine Syrett, Mrs Helen Dear and Mr P. Rowden for their assistance in the electron microscopy.

\section{REFERENCES}

Almeida, J. D. \& Waterson, A. P. (1969). The morphology of virus-antibody interaction. Advances in Virus Research 15, 307-338.

ARko, R. J. (1972). Neisseria gonorrhoeae: experimental infection in laboratory animals. Science, New York I77, I 200-I 20I.

Buchanan, T. M., Swanson, J., Holmes, K. K., Kraus, S. J. \& Gotschlich, E. C. (I973). Quantitative determination of antibody to gonococcal pili. Journal of Clinical Investigation 52, 2896-2909.

Difco Manual, 7th edn. (1971), pp. 122-123. Detroit: Difco Laboratories.

Jephcott, A. E., Reyn, A. \& Birch-Andersen, A. (1971). Neisseria gonorrhoeae. II. Demonstration of presumed appendages to cells from different colony types. Acta pathologica et microbiologica scandinavica B 79, 437-439.

Kellogg, D. S., Peacock, W. L., Jun., Deacon, W. E., Brown, L. \& Pirkle, C. I. (I963). Neisseria gonorrhoeae. I. Virulence genetically linked to clonal variation. Journal of Bacteriology 85, 1274-1 279.

LAWn, A. M. \& MeYNell, E. (1970). Serotypes of sex pili. Journal of Hygiene 68, 683-694.

Novotny, P., Short, J. A. L. \& WALKer, P. D. (1975). An electron microscope study of naturally occurring and cultured cells of Neisseria gonorrhoeae. Journal of Medical Microbiology (in the Press).

Swanson, J. (1973). Studies on gonococcus infection. IV. Pili: their role in attachment of gonococci to tissue culture cells. Journal of Experimental Medicine 137, 571-589.

TURner, W. H. \& Novotny, P. (1974). Immune electron microscopy of Neisseria gonorrhoeae pili. Proceedings of the Society of General Microbiology 2, 18. 